\title{
DOES CORPORATE GOVERNANCE MATTER FOR ASSET QUALITY OF ISLAMIC BANKS?
}

\author{
Ejaz Aslam*, Aziz Ur-Rehman ${ }^{* *}$, and Anam Iqbal ${ }^{* * *}$ \\ * Corresponding author. School of Islamic Economics, Banking \& Finance, Minhaj University \\ Lahore, Pakistan. Email: ejazaslam95@gmail.com \\ ${ }^{* *}$ IIUM Institute of Islamic Banking and Finance (IIiBF), Malaysia. Email: Mufti.Aziz@hotmail.com \\ ${ }^{* * * *}$ IIUM Institute of Islamic Banking and Finance (IIiBF), Malaysia. \\ Email: anam.iqbal5050@gmail.com
}

\begin{abstract}
This study investigates the impact of corporate governance on asset quality of Islamic banks by employing data on 129 Islamic banks from 29 countries spanning the period from 2008 to 2017 . The study shows that asset quality of Islamic banks is positively and significantly sensitive to an increase in board independence, Shariah board, and audit committee effectiveness. The study finds that female participation in management as CEOs seems to detract from good performance and that more board meetings can be harnessed to improve banks' asset quality. These empirical findings have practical policy implications regarding asset quality management and board construction within the Islamic banking sector.
\end{abstract}

Keywords: Corporate governance; 2SYS-GMM; Loan to assets; Loan to deposit; Nonperforming loans; OIC countries.

JEL Classifications: G18; G21; G34; H81.

Article history:

Received : June 08, 2020

Revised : December 18, 2020

Accepted : January 04, 2021

Available online : June 30, 2021

https://doi.org/10.21098/bemp.v24i2.1344 


\section{INTRODUCTION}

The dynamic challenge of corporate governance and its relation to performance have attained ever-growing popularity during the two decades (Aslam and Haron, 2020). A fundamental limitation of this comprehensive literature is an inability to portray how professional and social correspondence between board individuals affect the capacity of board members to perform their obligations and to avoid corporate scandals. Corporate scandals have an impact on both the investor's certainty and economic recessions, and hence highlight the utmost significance of corporate governance across firms (Nomran and Haron, 2020) and the banking sector. A delicate corporate governance system and extreme risk-taking exposures enhance the banking sector unsteadiness and economic losses; this reinforces the need for effective corporate governance practices in the banking sector (Aslam and Haron, 2020b). Rehman et al. (2020) discussed that a board demanding a good governance structure could send a positive signal to the market as well as provide good advice to management, which could significantly contribute to sustainable banking performance through strategic decision-making leads.

Likewise, corporate governance and asset quality in the banking sector have recently received extraordinary attention from enterprises, governments and worldwide associations, especially in the aftermath of the global financial crisis of 2007/2008 (Chazi et al., 2018). Noteworthy, the conventional banking sector has been negatively impacted by the financial crisis, whereas the Islamic banking sector has remained stable and less vulnerable due its unique structure. ${ }^{1}$ Despite the exponential growth of Islamic banks, they face challenges of assets deficiency (Fiador and Sarpong-Kumankoma, 2020). Thus, it is the failure of management to antagonistic for any bank to deploy their assets within the pre-defined timeframe (Ahamed, 2017). Therefore, bank loans are viewed as an advantage for banks; however, the presence of non-performing loans will disintegrate the nature of the benefits of bank loans. Non-performing loans create adverse liquidity effects, which in turn distress the banks', particularly reducing their future profits. Thus, a bank's asset quality is one of the imperative measures used in deciding the wellbeing of the bank (Aspiranti and Amaliah, 2019).

The rapid growth of the Islamic financial industry has spurred scholarly interest in the issue of asset quality in Islamic banks (Naushad and Malik, 2015). The Islamic banking industry faces more competition. This intense competition turns into the primary driver of the development and steadiness of banks in the Islamic banking industry (Ahamed, 2017). In line with this reasoning, a challenge for the boards of Islamic banks is ensuring that all their banks' operations are compliant with Shariah law (prohibition of interest, gambling, and excessive risk); in attempts to be Sharia law compliant, Islamic banks experience decreasing asset efficiency (Ahmad et al., 2018; Chazi et al., 2018). John et al. (2016) recommend future research to explore the role of directors'/boards' in promoting asset quality of the banking sector. This study is motivated to fill this research gap in the literature and to offers an enhanced understanding regarding the role of directors/ boards in the Islamic banks' asset quality. Our study draws on the insights of

1 Juhro et al. (2020) outline some unique features of Islamic stocks (issued by banks and non-banks) that make them resilient to shocks. 
the 'resource dependence theory' and argues that Islamic banks can sustain their asset quality through good corporate governance structure because boardroom capabilities (important information, aptitude, and skill) and a better capacity to relieve the competitive uncertainties maintain sound loan profiles in Islamic banks. Specifically, good corporate governance fosters national and international trust of the customers and community, which is an indispensable requisite for the development of Islamic banks.

This study has several contributions. First, the evidence put forth by this study contributes to the literature on both corporate governance and banking by proposing an efficient board mechanism to enhance the banks' ability to improve their asset quality. Second, this study controls for unobserved endogeneity and heterogeneity, which were missed by the large portion of the literature. Third, we examine how effective the dual board structure in Islamic banks is, by estimating the statistical significance of the interaction term between the regular board of directors and Sharia board on the asset quality of Islamic banks. Lastly, as opposed to prior studies, this study examines how bank risk varies across four different continents by using diverse and updated data concerning Europe and Central Asia, Gulf Co-operation Council (GCC), non-GCC Middle East and North Africa (MENA), East Asia and Pacific, and South Asia. This permits our study to assess whether disparities in the cross-regional regulatory frameworks, legal systems, and Islamic banking practices lead to disparities in risk-taking behaviour between and conventional and Islamic banks.

The rest of the paper is organised as follows. Section II shows some of the leading measures of corporate governance along with the hypothesis. Section III presents the data and methodology of the study. Section IV presents the results on the relationship of corporate governance and asset quality of Islamic banks. Finally, Section V concludes.

\section{LITERATURE REVIEW}

\section{A. Asset Quality of Banks}

A steady banking system is essential for effective financial intermediation. Banks are dissimilar to assembling organizations; they sell credit and make a profit on their credit (advances). Thus, loans and advances are considered significant resources possessed by banks. Islamic banks' financing and advances in the form of sale, partnership, trade, and services are subject to Shariah compliance (Ahmad et al., 2018; Aslam and Haron, 2020). Therefore, there is a dire need for the banking sector to adequately oversee their (Islamic banks) financing (loans) to achieve its core objectives (Fiador and Sarpong-Kumankoma, 2020). As banks keep on financing, they are consistently susceptible to the risk of default from borrowers (Abdulazeez et al., 2019).

Several previous studies discussed asset quality in different dimensions. The study of Chazi et al. (2018) explored the core risks faced by banks, investors, and clients due to loan default. Several of the past studies identify the vital measures of banks' asset quality, which include: loan to deposit, loan to assets, non-performing loans to net loans, and non-performing loan to assets (Abdulazeez et al., 2019; Fakhrunnas and Ramly, 2017; Tarchouna et al., 2017). According to Abdulazeez et 
al. (2019), for better asset quality, banks should maintain the loan to deposit ratio below $85 \%$, and non-performing loan to net loans below 5\%. Moreover, Fiador and Sarpong-Kumankoma (2020) explained that banks with better asset quality have a low ratio of loans to total loans. Tarchouna et al. (2017) show that banks with a high ratio of loans to total assets take more risk to generate profit.

\section{B. Corporate Governance and Asset Quality of Banks}

Prior studies demonstrated that corporate governance is an essential determinant of financial performance and firm outcomes (Abdulazeez et al., 2019). Additionally, governance also entails frameworks and structures to lessen the issue of agency problems emerging among investors and the board of an organization (Ahamed, 2017). At the bank level, we expect that banks with better board structure will make better decisions, which will boost the banks' wealth. Thus, the viability of a board in executing its managerial obligations is affected by some other board features to a great extent. These features are board-related such as independence, size, committees, gender, qualification, meetings, and Shariah board (Aslam et al., 2019; John et al., 2016). In view of the current interests of banks, this study analyses the role of board independence, board size, CEO duality, Shariah board, and audit committee in improving the asset quality of Islamic banks. Therefore, our discussion primarily explores the following factors.

\section{B1. Board Size}

Aslam and Haron (2020b) explained that the board size (executives) of an organization forms the board's structure. Prior studies discussed the right and optimal board size in an organization, but this remains elusive. Organizations ascertained their ideal board size according to the trade-off among expenses and advantages for a larger and smaller board. Some firms accomplish better with larger boards since they face complications and require the advisory role of professional boards (Chazi et al., 2018; Mollah et al., 2017). Naushad and Malik (2015) documented that larger boards might be valuably possessing a vast array of knowledge, aptitudes, experience, and the expertise to advise the management to make better decisions in the interest of firms. Some earlier studies reported that smaller boards are valuable because larger boards have unreasonable control over CEOs and obstruct the adequacy of their decision making (Farag et al., 2018). Chazi et al. (2018) reported that a large board size does not just expand board cost, board repetition, and the issue of free-riding from inept board individuals, it creates additionally pointless board debates emerging from contradictions. Considering the conclusions of prior studies, we deduct that Islamic bank required a larger board to make efficient strategic decisions in a competitive environment. Thus, we formulate the following hypothesis:

H1: Larger boards exert a positive effect on the asset quality of Islamic banks.

\section{B2. Board Independence}

Board independence is a significant component of board composition, measured as the total outside directors share in the board (Tarchouna et al., 2017). Farag et al. 
(2018) documented that non-executive directors provided more effectual advisory and monitoring role that is unavailable within the organization. Tarchouna et al. (2017) found that organizations possessed higher asset quality because of active monitoring role of outside directors. Moreover, Wang et al. (2012) stated that board independence has a positive and significant effect on the asset quality of the US bank holding companies. Hence, Almutairi and Quttainah (2017) documented that outside directors are less compelling for observance being subject to the CEO for their career growth. Mollah et al. (2017) pointed out that non-executive directors help to encourage the exchange of data between the management and directors. A high proportion of outside directors could, thus, weaken the performance of the advisory tasks in the organization (Aslam, and Haron, 2020b). Tarchouna et al. (2017) additionally found a noteworthy negative connection between board independence and non-performing loans. Their outcomes are consistent with those of Japanese insider-ruled corporate administration highlights. Thus, the study of Aslam and Haron (2020b) found that board independence is primarily related to banking industry using data from several OECD countries. This study hypothesises that the Islamic financial industry utilises board independence effectively. This hypothesis is stated as follows.

H2: Board independence exerts a positive effect on the asset quality of Islamic banks.

\section{B3. CEO Duality}

CEO duality exists when the CEO of an association additionally serves or acts as the chairman of the board (Grassa and Matoussi, 2014). In this manner, the CEO wields absolute power and supremacy over all corporate decisions. Thus, separating the roles of the CEO and the Chairman will improve responsibility, as the autonomous board will fill in to keep an eye on the activities and decisions of the firm through joint participation thereby guaranteeing that investors' interest is very much ensured (Al-Malkawi and Pillai, 2018). Nguyen et al. (2015) argued that board duality and partitioning of roles have their own merits and demerits. They also contended that combining the two positions will energize a substantial initiative and improve an organisation's performance over the long haul. Similarly, Tarchouna et al. (2017) stated that in the presence of board duality and a strong executive, there exists an immediate connection between corporate proficiency and execution. In this spirit, we predict that board duality has a beneficial impact on the asset quality of the Islamic banks (Almutairi and Quttainah, 2017). Our hypothesis is formulated as follows.

H3: CEO duality exerts a positive effect on the asset quality of Islamic banks.

\section{B4. Audit Committee}

Audit committee is a standing committee of governance that is established to enhance the financial accountability, unwavering quality, and transparency in organisations, whereby the auditor and the management strengthen the financial reporting in the organizations according to the general accounting and legal standards (AlSagr et al., 2018). It also serves as a scaffold in the correspondence network among auditors and board of directors as well as enable them to adequately 
check the power of the board with specific reference to the accounting standards (Rehman et al., 2021). Therefore, the Combined Code (2008) suggested that all listed organizations have a completely independent audit committee. Several studies found conflicting results by analysing the appropriate audit committee size and financial reporting (Al-Karasneh, 2018). For instance, Al-Malkawi and Pillai (2018) demonstrated that larger audit committees are bound to withstand pressures of management conspiracy and have the option to give more consideration to the overall financial accounting process. Thus, regulatory bodies also believe that audit committee size is a significant component of controlling the accounting process. Hence, the study of Alam and Haron (2020) reported that large size committees depend on a more extensive information base, changed aptitude, and subsequently attempt their job even more successfully. Along with this discussion, we believe that the audit committee plays a significant role in improving the asset quality of Islamic banks and hence we formulate our hypothesis as follows.

H4: Larger audit committees exert a positive effect on the asset quality of Islamic banks.

\section{B5. Shariah Board}

Islamic banks have double layer governance structure: the regular board of directors and Shariah board. The ordinary board perform like a regular bank board. Yet, it works under the two-tier governance structure-the regular board of directors inside the strict parameters set out by the Shariah board (Nomran and Haron, 2020). The job of the Shariah board is to implement and ensure Islamic standards at all levels of board and evaluating the performance Mollah et al. (2017). The Shariah board ensures great corporate governance for an Islamic bank. Thus, the primary function of the Shariah board to complies with all the transaction of Islamic banks in accordance with Islamic law and avoid the violation of Shariah. The resource dependence theory proposes that a larger Shariah board size brings diverse knowledge and experience, which enable the board to provide better quality guidance and counsel to the organizations (Rehman et al., 2021). Moreover, several studies stated that larger Shariah boards have professional knowledge and a good understanding of Islamic law that enable them to take better decisions to improve the banking efficiency (Mollah et al., 2017; Nomran and Haron, 2020). Accordingly, the study hypothesizes that:

H5: Large Shariah board size exerts a positive effect on the asset quality of Islamic banks.

\section{RESEARCH METHODOLOGY}

\section{A. Data Collection Procedure}

The sample contains all listed Islamic banks in the Bankscope database spanning the period from 2008 to 2017. The internal governance-related data are collected from banks' annual reports, which are openly available on their websites, and the financial data are obtained through the Bankscope database. Data on the macroeconomic variables are collected from the World Bank Indicators (WDI) database. We construct a balanced panel dataset and removed all those banks with missing accounting and governance data as well as those that are unalive 
throughout the sample period. Moreover, we also eliminate all Islamic investment banks and Modarabah funds from the sampling frame. This procedure results in a balanced panel of 129 Islamic banks from 29 Organisation of Islamic Cooperation (OIC) countries, yielding 1290 observations, as shown in Table 1.

Table 1.

\section{Study Sample}

This table shows the sample of Islamic banks from 29 OIC countries.

\begin{tabular}{|c|c|c|}
\hline Number & Countries & Numbers of IBs \\
\hline 1 & Azerbaijan & 1 \\
\hline 2 & Bahrain & 14 \\
\hline 3 & Bangladesh & 5 \\
\hline 4 & Brunei Darussalam & 3 \\
\hline 5 & Egypt & 3 \\
\hline 6 & Libya & 2 \\
\hline 7 & Indonesia & 8 \\
\hline 8 & Iran (Islamic Republic of Iran) & 3 \\
\hline 9 & Iraq & 7 \\
\hline 10 & Jordan & 7 \\
\hline 11 & Kuwait & 2 \\
\hline 12 & Kyrgyzstan & 1 \\
\hline 13 & Lebanon & 4 \\
\hline 14 & Malaysia & 15 \\
\hline 15 & Maldives & 2 \\
\hline 16 & Mauritania & 1 \\
\hline 17 & Nigeria & 1 \\
\hline 18 & Oman & 2 \\
\hline 19 & Pakistan & 9 \\
\hline 20 & Qatar & 6 \\
\hline 21 & Saudi Arabia & 5 \\
\hline 22 & Senegal & 1 \\
\hline 23 & Sudan & 9 \\
\hline 24 & Syrian Arab Republic & 1 \\
\hline 25 & Tunisia & 1 \\
\hline 26 & United Arab Emirates & 7 \\
\hline 27 & Turkey & 4 \\
\hline 28 & West Bank and Gaza & 2 \\
\hline \multirow[t]{2}{*}{29} & Yemen & 3 \\
\hline & Total Sampled of Islamic Banks & 129 \\
\hline
\end{tabular}

B. The Variables

In this study, we collected data on Loan to Assets (LAS), Loan To Deposit (LTD), and Non-Performing Loan to net loans (NPLR), which are recognized as the measures of banks' asset quality in the literature (Al-Karasneh, 2018; Fakhrunnas and Ramly, 2017). The explanatory variables are Board Independence (BIND), Board 
Size (BS), CEO Duality (CD), Shariah Board (SB), and Audit Committee (AUDC), following the previous research (Aslam and Haron, 2020a; Aslam et al., 2019). Control variables are bank-specific (market share, net profit, size, and leverage) and board features (gender and board meetings, and country-specific features (GDP and inflation) selected from previous studies on corporate governance and asset quality (Almutairi and Quttainah, 2017; Farag et al., 2018; Grassa and Matoussi, 2014; Mahmood et al., 2014; Mollah et al., 2017; Shabbir et al., 2020). Table 2 summarizes all variables used in this study.

\section{Table 2.}

\section{The Variables}

This table describes the variables used in this study. These variables are divided into three categories. The first category has the corporate governance mechanism-related independent variables. The second category has asset quality-related dependent variables. The third category has the control variables, which is categorised into bankspecific, board-specific, and macroeconomic variables.

\begin{tabular}{|c|c|c|}
\hline Variables & Labels & Definition \\
\hline \multicolumn{3}{|c|}{ Corporate governance mechanisms (Independent variables) } \\
\hline Board Size & BS & Total number of members on the board \\
\hline $\begin{array}{l}\text { Board } \\
\text { Independence }\end{array}$ & BIND & Total number of members of non-executive directors \\
\hline CEO Duality & $\mathrm{CD}$ & $\begin{array}{l}\text { If the } \mathrm{CEO} \text { also holds chairman position, then the value is one and if } \\
\text { not then the value is zero }\end{array}$ \\
\hline Shariah Board & SB & Total number of members of Shariah Board \\
\hline Audit Committee & AUDC & Total number of members in the audit committee \\
\hline \multicolumn{3}{|c|}{ Bank asset quality indicators (Dependent variables) } \\
\hline Loan to assets & LAS & Ratio of average total loans to average total assets \\
\hline Loan to deposit & LTD & Ratio of average total loans to average total customer deposits \\
\hline $\begin{array}{l}\text { Non-performing } \\
\text { loan to net loans }\end{array}$ & NPLR & Ratio of non-performing loans to net loans \\
\hline \multicolumn{3}{|c|}{ Bank characteristics (Control variables) } \\
\hline Bank Size & BKS & Natural log of total bank assets \\
\hline Leverage & LEV & Proportion of total debt over equity \\
\hline Net Profit & $\mathrm{NP}$ & Total revenue minus total expenses \\
\hline Market Share & MKS & Share of assets of each bank to total banks' assets \\
\hline Foreign ownership & FOWN & $\begin{array}{l}\text { A binary variable that takes the value of one if foreign firms have an } \\
\text { ownership in the Islamic bank or zero otherwise }\end{array}$ \\
\hline \multicolumn{3}{|r|}{ Board features (Control variables) } \\
\hline Gender & GEND & $\begin{array}{c}\text { If the CEO is male the value is one and if the CEO is female, then the } \\
\text { value is zero }\end{array}$ \\
\hline Board Meetings & $\mathrm{BM}$ & Total number of board meetings \\
\hline \multicolumn{3}{|c|}{ Macroeconomic features (Control variables) } \\
\hline Inflation & CPI & Natural log of the consumer price index \\
\hline Country Growth & GDP & Natural log of total gross domestic product \\
\hline
\end{tabular}

\section{Model Specification}

To address endogeneity and heterogeneity problems, the 2SYS-GMM estimator is employed and the following specifications are tested: 


$$
\begin{aligned}
& L A S_{i t}=\alpha_{0}+\alpha_{1} L A S_{i t-1}+\sum_{i=1}^{5} \beta_{i} C G_{i t}+\sum_{i=1}^{7} \delta_{i} X_{i t}+\varepsilon_{i t} \\
& L T D_{i t}=\alpha_{0}+\alpha_{1} L T D_{i t-1}+\sum_{i=1}^{5} \beta_{i} C G_{i t}+\sum_{i=1}^{7} \delta_{i} X_{i t}+\varepsilon_{i t} \\
& N P L R_{i t}=\alpha_{0}+\alpha_{1} N P L R_{i t-1}+\sum_{i=1}^{5} \beta_{i} C G_{i t}+\sum_{i=1}^{7} \delta_{i} X_{i t}+\varepsilon_{i t}
\end{aligned}
$$

where $i$ denotes the Islamic banks $(i=1, \ldots, 129)$ and $t$ denotes the years $(t=2008$ $, \cdots, 2017)$. LAS is a loan to assets, LTD loan to deposit, NPLR is a non-performing loan to net loans indicator of the asset quality of Islamic banks. CG denotes the corporate governance variables. $X$ indicates the control variables (gender, board meetings, market share, net profit, bank size, leverage, GDP, inflation) and ${ }^{\varepsilon}$ is the error term. Because the estimated standard errors using the 2SYS-GMM estimator can be bias downwards, we employ the finite sample correction for the variancecovariance matrix proposed by Windmeijer (2005).

\section{Descriptive Statistics}

Our preliminary descriptive analysis shows that the mean ratio of Loan to Assets (LAS) is approximately $50.4 \%$ and varies between $4.4 \%$ to $1020 \%$. $^{2}$ The mean of Loan To Deposit (LTD) is almost $418 \%$ and varies between $1.5 \%$ to $2051 \%$. Additionally, the average of Non-Performing Loans to net loans (NPLR) is $403 \%$ and varies between $326 \%$ to $3176 \%$. Concerning corporate governance, the average Board Size (BS) is 8.5 and varies between 5 to 21 . Moreover, the average of Board Independence (BIND) is 4.5 and varies between 3 to 13. The mean value of the Shariah board is 3.71 and varies between 2 to 11 . The average size of the audit committee is 3.46 and varies between 2 to 7 . Moreover, the average size of CEO Duality, board meeting, gender is $0.17,4$, and 0.86 , respectively. Turning to the bank and macroeconomic variables, the mean bank size, leverage, market share, net profit, GDP, and inflation, and foreign ownership are, respectively, 6.08, 7.06, 2.06, 0.05, 27.91, 4.74, and 0.20.

\section{E. Correlation Statistics}

From the correlation analysis, we find that non-executive directors' indicator has the highest correlation (0.69) with board size. ${ }^{3}$ Thus, none of the correlation coefficients exceeds 0.69 ; therefore, we conclude that collinearity between the variables is not a concern, as suggested by Gujarati (2009). Additionally, we find that the Variance Inflation Factor (VIF) of all explanatory variables is less than 10.

2 The full results are withheld but are available on request.

3 The results are available on request. 
Based on this, there is no concern of multi-collinearity among the regressors, as suggested by Wooldridge (2005). ${ }^{4}$

\section{RESULTS AND DISCUSSION}

Table 3 reports the results of the 2SYS-GMM estimation of the effect of corporate governance on Islamic banks' asset quality in Equations (1) and (2). For each regression, the diagnostic test satisfies the condition that instruments are uncorrelated and that the error terms are different across models. In addition, the AR (1) and (2) test results show absence of autocorrelation problems across models, as suggested by the literature (Nomran and Haron, 2020; Aslam and Haron, 2020b). The lag values of LAS, LTD, and NPLR are positive and statistically significant in all models, indicating that the past year's LAS, LTD, and NPLR values significantly enhance the current year's LAS, LTD, and NPLR values of Islamic banks.

Table 3 indicates that Board Size (BS)is negatively related to the loan to assets value of the Islamic banks. These results support the finding of Almutairi and Quttainah (2017): board size reduces asset quality of banks. Thus, the negative relationship might be because of Islamic banks' directors who avoid taking excessive risk and avoid non-Shariah compliant investment. On the other hand, BS is positively related to the loan to deposit value of Islamic banks, in line with the finding of Abdulazeez et al. (2019) on Nigeria. This result indicates that a larger board enhances the Islamic banks' asset quality measured in terms of LTD. Also, BS has a negative and significant relationship with Non-Performing Loan to net loans (NPLR) value of the Islamic banks, consistent with the findings of Tarchouna et al. (2017) in the USA. This result indicates that board size is characterized by diversified skills and experience, which enable them to reduce the ratio of nonperforming loans in Islamic banks.

Board Independence (BIND) is positively related to the asset quality of Islamic banks measured in terms of LAS and LTD. The results support the argument put forward Chazi et al. (2018) that more independent boards improve the asset quality of banks. Thus, a more independent board is more competent and has diversified knowledge in utilizing assets properly and hence improves the wealth of Islamic banks. BIND is negatively related to NPLR, supporting the findings of Fakhrunnas and Ramly (2017) on Southeast Asian banks. This result signifies that board independence helps the Islamic banks to reduce their non-performing loans. CEO Duality (CD) is positively related to LAS and LTD, consistent with the findings of Al-Malkawi and Pillai (2018) on Qatar that CEO duality improves the asset quality of banks. Moreover, CD is negatively related to NPLR, which is similar to the findings of Grove et al. (2011) showing that CEO duality improves the asset value of banks. This result indicates that one manager has more power to make better decision to enhance the asset quality of Islamic banks.

4 These results are also available on request. 
Table 3.

\section{Impact of Corporate Governance on Asset Quality (2SYS-GMM)}

This table reports estimates of Equations (1) to (3) using the 2SYS GMM estimator. Equations (1) to (3) are as follows:

$L A S_{i t}=\alpha_{0}+L A S_{i t-1}+\sum_{i=1}^{5} B_{1} C G_{i t}+\sum_{i=1}^{7} B_{2} X_{i t}+\varepsilon_{i t}$
$L T D_{i t}=\alpha_{0}+L T D_{i t-1}+\sum_{i=1}^{5} B_{1} C G_{i t}+\sum_{i=1}^{7} B_{2} X_{i t}+\varepsilon_{i t}$
$N P L R_{i t}=\alpha_{0}+N P L R_{i t-1}+\sum_{i=1}^{5} B_{1} C G_{i t}+\sum_{i=1}^{7} B_{2} X_{i t}+\varepsilon_{i t}$

$* * *, * *$, and * represent, respectively, statistical significance at the $1 \%, 5 \%$, and $10 \%$ levels. AR (1) and (2) and Hansen test results are reported in parentheses.

\begin{tabular}{|c|c|c|c|}
\hline Variable & $\begin{array}{c}\text { Model } 1 \\
\text { Loan to assets }\end{array}$ & $\begin{array}{c}\text { Model } 2 \\
\text { Loan to deposit }\end{array}$ & $\begin{array}{c}\text { Model } 3 \\
\text { Non-performing } \\
\text { loan to net loan }\end{array}$ \\
\hline Loan to assets & $0.0984^{* * *}$ & & \\
\hline Loan to deposit & & $0.3228^{* * *}$ & \\
\hline Non-performing loan to net loan & & & $0.1473^{* * *}$ \\
\hline Board size & $-0.0539^{* * *}$ & $0.6968^{* * *}$ & $-0.6225^{* *}$ \\
\hline Board Independence & $0.0352^{* * *}$ & $0.3468^{* * *}$ & $-1.5447^{* * *}$ \\
\hline CEO duality & $0.1018^{* *}$ & $9.1257^{* * *}$ & $-11.2518^{* * *}$ \\
\hline Shariah board & $0.0411^{* * *}$ & $1.1241^{* * *}$ & $-1.7584^{* * *}$ \\
\hline Audit committee & 0.0931 & $2.2544^{* * *}$ & $-4.8889^{* * *}$ \\
\hline CEO gender & $0.1060^{* * *}$ & $2.6692^{* * *}$ & $-2.0594^{*}$ \\
\hline Board meeting & $0.0019^{* *}$ & $1.2133^{* * *}$ & $0.0021^{*}$ \\
\hline Bank size & $-0.0183^{* * *}$ & 0.1857 & -0.2834 \\
\hline Leverage & $0.0091^{* * *}$ & $-0.0527^{*}$ & -0.0925 \\
\hline Net profit & $-0.0187^{* * *}$ & $-0.3664^{* * *}$ & $1.0287^{* * *}$ \\
\hline Market share & $0.6384^{* * *}$ & $7.1486^{* * *}$ & $-23.4225^{* * *}$ \\
\hline Foreign ownership & $0.2597^{* * *}$ & $8.2465^{* * *}$ & $-13.4985^{* * *}$ \\
\hline Inflation & $-0.0161^{* * *}$ & $-0.4425^{* * *}$ & -0.3553 \\
\hline GDP & $0.0124^{*}$ & $1.6073^{* * *}$ & 0.3939 \\
\hline Constant & $0.0548^{* * *}$ & $0.76005^{* * *}$ & $-0.9007^{* * *}$ \\
\hline Year dummy & Yes & Yes & Yes \\
\hline Crisis dummy & Yes & Yes & Yes \\
\hline Observations & 1165 & 1165 & 1171 \\
\hline Number of Individuals & 129 & 129 & 129 \\
\hline Number of Instruments & 8 & 9 & 9 \\
\hline AR (1) test statistics ( $p$-value) & 0.1728 & 0.0749 & 0.3025 \\
\hline AR (2) test statistics ( $p$-value) & 0.2513 & 0.2405 & 0.3782 \\
\hline Hansen test ( $p$-value) & 0.3718 & 0.2665 & 0.6494 \\
\hline
\end{tabular}

Shariah Board $(S B)$ is positively related to $L A S$ and $L T D$. These results support the finding of Naushad and Malik (2015) that larger Shariah boards improve the asset quality of Islamic banks. Moreover, SB is negatively related to NPLR, supporting the findings of Fakhrunnas and Ramly (2017) for Southeast Asian Islamic banks. Thus, the present results signify that SB fosters a positive managerial behaviour to improve the asset quality of Islamic banks by offering additional support to boards. On the other hand, AUDC is positively associated with LTD but 
is not associated with LAS. These results support theoretical arguments and are similar to the finding of Wang et al. (2012) and Tarchouna et al. (2017) for the USA. The present findings indicate that large audit committee size helps the Islamic banks to reduce their non-performing loans. Moreover, these are consistent with the resource dependence theory that large independence audit committees have the latitude of making informed decisions, detecting errors and can easily facilitate effective work and provide unbiased judgment, resulting in improved asset quality of Islamic banks.

For the control variables, we observe that gender is positively related to LAS and LTD but negatively associated with NPLR. These results support the finding of Grassa and Matoussi (2014) that male CEOs have a beneficial effect on the asset quality of the banks. Board meetings are positively related to LAS and LTD, consistent with Aslam and Haron (2020a) that more board meetings improve the value of Islamic banks. Bank size is negatively associated with LAS, which contradicts evidence in Abdulazeez et al. (2019). This result indicates that as the size of the bank increases, the size of non-performing loans increases and in turn deteriorates asset quality of the Islamic banks. Leverage is negatively related to LAS and LTD suggesting that a high ratio of debt has a detrimental effect on the asset quality of Islamic banks, consistent with Aslam and Haron (2020b) that more debt decreases the performance of Islamic banks.

Net profit has a negative relation with LAS and LTD but a positive one with NPLR. These results imply that an increase in profit decreases the asset quality of Islamic banks. One of the possible reasons for this reduction effect of an increase in profit on asset quality is that an increase in bank lending simultaneously increases profit and the ratio of bad debt. Market share is positively associated with LAS and LTD, but is negatively related to NPLR. These results indicate that a large share of Islamic banks in the market enhances the asset quality of Islamic banks, consistent with the finding of Aslam and Haron (2020a) in OIC countries. Foreign ownership is positively associated with LAS and LTD, which supports the finding of Aslam and Haron, (2020) that, in the presence of foreign ownership, banks perform more efficiently and thus have better asset quality of Islamic banks. Inflation carries a negative relation with LAS and LTD indicating that high inflation decreases the asset quality of Islamic banks because people are unable to pay their debt. GDP positively impacts LAS and LTD, consistent with Mollah et al. (2017).

\section{ROBUSTNESS CHECKS}

In this section, we estimate our models using the one-step first-difference Generalized Method of Moments (difference GMM) estimator to investigate the robustness of our results in Table $6^{5}$. We find that the coefficients of other CG variables, including board size, board independence, CEO duality are unchanged, in terms of direction and magnitude. All the asset quality lag variables, namely LAS, LTD, and NPLR, have a positive effect on the performance of Islamic banks, similar to the estimates in Table 3. The coefficients of the control variables in this case have similar directions and significance as those reported in Table 3.

These estimates are available on request. 


\section{CONCLUSION}

There is an ongoing debate regarding the role of corporate governance in improving the value of corporations, especially after the global financial crisis of 2008. Weak corporate governance in the financial sector was deemed as the principal root of the global financial crisis of 2008, and this corporate governance weakness is not limited to the commercial banks - it extends to Islamic banks as well. Therefore, this study adds to the debate about the significant role of corporate governance in improving the asset quality in Islamic banks by using a panel dataset of 129 Islamic banks operating in 29 OIC countries spanning 2008 to 2017. Based on the 2SYS-GMM estimator, we find that the lag values of loan to assets, loan to deposit, and non-performing loans to net loans have a positive and significant effect on the present values of loan to assets, loan to deposits, and non-performing loans to net loans of Islamic banks. We find that board independence, Shariah board, and audit committee play a significant role in enhancing the asset quality of Islamic banks. Still, board size and CEO duality have effects on the asset quality of Islamic banks. Thus, the findings indicate that reliable corporate governance mechanisms play a pivotal role in enhancing the asset quality of the Islamic banks.

Sequel to the present empirical evidence, this study would help the banks in developing appropriate strategies to improve their asset quality. In essence, larger board sizes may be beneficial to Islamic banks if they are motivated to utilize their services and their expertise to add value. It is also imperative that the board independence would ensure the effective monitoring of the activities of the board, specifically concerning the credit department. Audit committee and Shariah board can foster positive managerial behaviours and asset quality of Islamic banks by offering additional support to the boards. They also increase the reliability, credibility, and legitimacy of Islamic banks, which boost the confidence of the investors, and as a result, improve banks' value. Moreover, male as CEOs take more reliable decisions than females, according to the results. This means, in some sense, that the role of female CEOs requires further investigation to map out the part of gender in the Islamic banking sector. Finally, more board meetings enhance the asset value of banks by efficiently monitoring the credit-related operation in the banks.

This study encourages the policymakers, regulators, and practitioners of Islamic banks to adopt effective governance mechanism to boost the asset quality of the Islamic banking industry.

\section{Acknowledgement}

The authors are grateful to the anonymous referees and editor of the journal for their extremely useful suggestions to improve the quality of the article. 


\section{REFERENCES}

Abdulazeez, D. A., Lawal, T., \& Ibrahim, M. Y. (2019). Board Structure and Asset Quality of Listed Deposit Money Banks In Nigeria. Jurnal Riset Akuntansi dan Keuangan, 7, 1-18.

Ahamed, M. M. (2017). Asset Quality, Non-interest Income, and Bank Profitability: Evidence from Indian Banks. Economic Modelling, 63, 1-14.

Ahmad, S., Amjad, M., \& Aslam, E. (2018). Types of Interest in Islamic Law Analysis and Application. Pakistan Journal of Islamic Research, 18, 168-170.

Al-Malkawi, H. -A. N., \& Pillai, R. (2018). Analyzing Financial Performance by Integrating Conventional Governance Mechanisms into the GCC Islamic Banking Framework. Managerial Finance, 44, 604-623.

Almutairi, A. R., \& Quttainah, M. A. (2017). Corporate Governance: Evidence from Islamic Banks. Social Responsibility Journal, 13, 601-624.

AlSagr, N., Belkhaoui, S., \& Aldosari, A. (2018). The Effect of Corporate Governance Mechanisms on Bank Performance Evidence from Saudi Banking Sector. Asian Economic and Financial Review, 8, 1111-1125.

Aslam, E., \& Haron, R. (2020a). Does Corporate Governance Affect the Performance of Islamic Banks? New Insight into Islamic Countries. Corporate Governance: The International Journal of Business in Society, 20, 1073-1090.

Aslam, E., \& Haron, R. (2020b). The Influence of Corporate Governance on Intellectual Capital Efficiency: Evidence from Islamic Banks of OIC Countries. Asian Journal of Accounting Research, 5, 195-208.

Aslam, E., Haron, R., \& Ahmad, S. (2020). A Comparative Analysis of the Performance of Islamic and Conventional Banks: Does Corporate Governance Matter?. Int. J. Business Excellence, 20, Early Cite.

Aslam, E., Haron, R., \& Tahir, M. N. (2019). How Director Remuneration Impacts Firm Performance: An Empirical Analysis of Executive Director Remuneration in Pakistan. Borsa Istanbul Review, 19, 186-196.

Aslam, E., Kalim, R., \& Fizza, S. (2019). Do Cash Holding and Corporate Governance Structure Matter for the Performance of Firms? Evidence from KMI 30-and KSE 100-indexed Firms in Pakistan. Global Business Review, 20, 313-330.

Aspiranti, T., \& Amaliah, I. (2019). MSME's Acceleration Strategy based on Sharia Bank Financial Performance in Indonesia. MIMBAR: Jurnal Sosial dan Pembangunan, 35, 277-285.

Chazi, A., Khallaf, A., \& Zantout, Z. (2018). Corporate Governance and Bank Performance: Islamic Versus Non-Islamic Banks in GCC Countries. The Journal of Developing Areas, 52, 109-126.

Fakhrunnas, F., \& Ramly, Z. (2017). Board of Directors and Risk-taking Behavior of Islamic Banks in South East Asia. Tazkia Islamic Finance and Business Review, $10,162-177$.

Farag, H., Mallin, C., \& Ow-Yong, K. (2018). Corporate Governance in Islamic banks: New Insights for Dual Board Structure and Agency Relationships. Journal of International Financial Markets, Institutions and Money, 54, 59-77.

Grassa, R., \& Matoussi, H. (2014). Is Corporate Governance Different for Islamic Banks? A Comparative Analysis between the Gulf Cooperation Council and Southeast Asian Countries. International Journal of Business Governance and Ethics, 9, 27-51. 
Grove, H., Patelli, L., Victoravich, L. M., \& Xu, P. T. (2011). Corporate Governance and Performance in the Wake of the Financial Crisis: Evidence from US Commercial Banks. Corporate Governance: an International Review, 19, 418-436.

Gujarati, D. N. (2009). Basic econometrics. Tata McGraw-Hill Education, New York. McGRAW-Hill.

John, K., De Masi, S., \& Paci, A. (2016). Corporate Governance in Banks. Corporate Governance: An International Review, 24, 303-321.

Juhro, S. M., Narayan, P. K., Iyke, B. N., \& Trisnanto, B. (2020). Is There a Role for Islamic Finance and R\&D in Endogenous Growth Models in the Case of Indonesia?. Pacific-Basin Finance Journal, 62, 101297. https://doi.org/10.1016/j.pacfin.2020.101297

Mahmood, M., Khan, S., Ijaz, F., \& Aslam, E. (2014). Determinants of Profitability of Islamic Banking Industry : An Evidence from Pakistan. Business E Economic Review, 6, 27-46.

Mollah, S., Hassan, M. K., Al Farooque, O., \& Mobarek, A. (2017). The Governance, Risk-taking, and Performance of Islamic Banks. Journal of Financial Services Research, 51, 195-219.

Naushad, M., \& Malik, S. A. (2015). Corporate Governance and Bank Performance: A Study of Selected Banks in GCC Region. Asian Social Science, 11, 226-241.

Nguyen, T., Locke, S., \& Reddy, K. (2015). Does Boardroom Gender Diversity Matter? Evidence from a Transitional Economy. International Review of Economics \& Finance, 37, 184-202.

Nomran, N. M., \& Haron, R. (2020). Relevance of Shari'ah Governance in Driving Performance of Islamic Banks during the Financial Crisis: International Evidence. In Banking and Finance. IntechOpen.

Rehman, A. U., Aslam, E., \& Iqbal, A. (2021). Intellectual Capital Efficiency and Bank Performance: Evidence from Islamic Banks. Borsa Istanbul Review. Early Cite.

Shabbir, M. S., Aslam, E., Irshad, A., Bilal, K., Aziz, S., Abbasi, B. A., \& Zia, S. (2020). Nexus between Corporate Social Responsibility and Financial and Nonfinancial Sectors' Performance: A Non-linear and Disaggregated Approach. Environmental Science and Pollution Research, 27, 39164-39179.

Tarchouna, A., Jarraya, B., \& Bouri, A. (2017). How to Explain Nonperforming Loans by Many Corporate Governance Variables Simultaneously? A Corporate Governance Index is Built to US Commercial Banks. Research in International Business and Finance, 42, 645-657.

Wang, W.-K., Lu, W.-M., \& Lin, Y.-L. (2012). Does Corporate Governance Play an Important Role in BHC Performance? Evidence from the US. Economic Modelling, 29, 751-760.

Windmeijer, F. (2005). A Finite Sample Correction for the Variance of Linear Efficient Two-step GMM Estimators. Journal of Econometrics, 126, 25-51.

Wooldridge, J. M. (2005). Simple Solutions to the Initial Conditions Problem in Dynamic, Nonlinear Panel Data Models with Unobserved Heterogeneity. Journal of Applied Econometrics, 20, 39-54. 
This page is intentionally left blank 